\title{
The Importance of Disaster Learning Multimedia To Enhance Students' Preparedness
}

\author{
$1^{\text {st }}$ Chatarina Muryani \\ Universitas Sebelas Maret \\ Surakarta, Indonesia, 57126 \\ chatarinamuryani@staff.uns.ac.id
}

\author{
$2^{\text {nd }}$ Yasin Yusup \\ Universitas Sebelas Maret, \\ Surakarta, Indonesia, 57126 \\ yyfgeo@gmail.com
}

\author{
$3^{\text {rd }}$ Singgih Prihadi \\ Universitas Sebelas Maret, \\ Surakarta, Indonesia, 57126 \\ zienov@yahoo.co.id
}

\begin{abstract}
The aim of this research was to evaluate the importance of disaster learning multimedia in improving the students'understanding and preparedness of disaster for high school students. There are four disaster learning multimedia that were experimented in classroomie floods, landslides, eruption and tidal floods. After using the multimedia in the learning process, students were asked to fill out a questionnaire containing responses about the use of multimedia in the learning process. The result of the research showed that based on the questionnaire analysis, the use of disaster multimedia learning made the students understand more about the cause of disaster, the process of disaster, the impact of the disaster and the mitigation/adaptation that need to be done for disaster risk reduction. While the results of the test showed that the utilization of disaster learning multimedia was effective in improving students' preparedness in facing disaster.
\end{abstract}

Keywords- learning multimedia, disaster, students' preparedness

\section{INTRODUCTION}

Indonesia is a country that very vulnerable to various disasters. Frequent earthquakes and tsunamies happened due to Indonesian location which is in the world ring of fire; eruption frequently happened since there are about 127 active volcanoes in Indonesia; floods and landslides happened due to Indonesianlocation which is in the tropics with high rainfall volume. Besides, some areas in Indonesia are also hit by drought and forest fires. Based on 2017data, the National Disaster Management Agency (BNPB) recorded 2341 disaster events happened in Indonesia, consist of floods (787), tornado (716), landslides (614), forest and land fires (96), floods and landslides (76), drought (19), earthquake (20), tidal wave and abrasion (11), and volcanic eruption (2). The impacts caused by the disaster during 2017 recorded 377 people died and missing, 1,005 people injured and 3,494,319 people displaced and suffered. Physical damage caused by the disaster includes 47,442 damaged housing units, among which 10,457 were severely damaged, 10,470 were moderately damaged, and 26,515 were lightly damaged. (DIBI BNPB, 2017)

Since World Conference on Disaster Reduction18-22 January 2005 inKobe, Hyogo, Japan the paradigm of disaster management has shifted from emergency response management to risk management, with a shift on the focus from post disaster to pre-disaster (ISDR, 2005). The implementation of the paradigm shift is bydesigning disaster risk reduction programs of which one of them isinserting disaster education into government official programs. The disaster management paradigm shifting from emergency to risk management with a clear focus from the post-disaster phase to the predisaster phase also contributes to a growing number of educated professionals at a minimum level to understand the relationship between various disciplines related to disaster risk reduction (Demeter, K.)

Education is a key mechanism through which children can participate in disaster risk reduction (DRR) (Amri, 2015).Education has always been one of the priorities in the global commitment for DRR, as articulated in the Yokohama Strategy (United Nations, 1994), the Hyogo Framework forAction (HFA) 2005-2015 (UNISDR, 2005),Starting from 2009, the Indonesian government has piloted a DRR schools project originally named "disaster-prepared schools" (or Sekolah Siaga Bencana in Bahasa) but now called "disaster-safe schools" (or Sekolah Aman Bencana in Bahasa). According to a government report from 2013, there are more than 25000 schools that have implemented the disaster-safe schools programme supported by government agencies and/or NGOs (Amri, 2017). In the curriculum of 2013 for senior high school, learningdisaster is inserted into one of the Basic Competencies at Geography subjects.

The development of DRR skills among children and adults is one of the most urgent challenges of modern society. Schools can play an important role in DRR because they often are important centers of community life. Therefore, schools directly impact 
not only the lives of teachers, students, parents and their relatives, but also the community as a whole. The majority of children spend most of their time at school and the school environment can determine their future destiny (UNICEV, 2011).

World-wide researchhas shown that using constructivism and multimedia technology has becoming increasingly important in teaching and learning in higher education in order to promote and enhance the teaching and learning process (Shaziti 2000; Wong, Kamariah \& Tang, 2003) when set within authentic contexts (Herrington, Reeves, Oliver \& Woo, 2004),. This enables teachers to better transfer knowledge to their students in the classrooms (Wong et. al, 2003). The study was aimed to determine whether the use of multimedia in learning disasters can increase the knowledge and preparedness of the students toward disaster.

\section{METHOD}

This research has successfully developed four disaster learning multimedia there are flood, landslide, eruption, andtidal flood. The product was developed using ADDIE model and has been validated by media experts and material experts. Multimedia was completed with images, maps, videos and animations that were mostly recorded and created by the research team. The stage which was curently done by the researcher was the testing stage in which four learning multimedia applied in the classroom to determine the effectiveness of disaster learning multimedia in improving understanding and preparedness of the students toward disaster.

Experiment schools were selected in which that their students have experienced disasters. The flood multimedia was tested in SMA Negeri 2 Karanganyar, the landslide multimedia was tested in MTA 1 Surakarta, eruption multimedia was tested in SMAN Cangkringan Sleman District and for tidal flood multimedia tested in SMAN Sayung Demak District. The research method used quasi-experiment, in each location there were one experiment class (using multimedia) and one control class (conventional methods) which were determined randomly. At the end of the learning, students were given a questionnaire to determine the the students responses toward the use of the multimedia, while in order to determine the effectiveness of the multimedia in improving the students' disaster preparedness, a test was given.

The post test questions used have been tested to evaluate the validity and reliability. From the 24test items that were prepared 6 items were failedremaining 18 items to be used. Data analysis used was one way anava.

\section{RESULTS AND DISCUSSION}

\section{A. Product Development}

For two years (2015-2016) the research has successfully developed four disaster learning multimedia named flood, landslide, eruption and tidal flood. The products were developed using ADDIE model ie Analysis, Design, Development, Implementation and Evaluation. Learning multimedia were arranged in the following order: apperception (a general description of why Indonesia is often hit by disaster), disaster-causing factors (theory with photos or videos taken from real sample in the field), disaster occurrence processes (animated theories created by the research team), disasters impact (described using maps, pictures or video), disaster mitigation and adaptation (theory with photo sample), closing (invitation for disaster prevention) and evaluation test. It is in line with the opinion of Crichton \& Kopp (2006) that multimedia learning should be an integrated medium of text, graphics, video, animation and sound). The superiority of this learning multimedia are the description which use simple term and language, most of the photos and video which are recorded in the real life phenomenon around the site, and the animation which was created by the research team.

- Flood learning Multimedia

Phenomenon that raised are, the Gadjahmungkur Wonogiri reservoir as flood control, land degradation at upstream Solo Drainage Basins, Bengawan Solo flood, the impact of flooding Bengawan Solo river for resident in Surakarta city and flood control effort with embankment, resettlement of riverbank.

- Landslide learning Multimedia

Photos and videos are recorded in Karanganyar and Boyolali districts of Central Java, especially in the landslide-prone areas of Jatiyoso sub-district, Ngargoyoso sub-district (Karanganyar district) and, Selo sub-district in Boyolali district. Animation of landslide types was created to clearlyshow the process of landslide.

- Eruption learning Multimedia

Examples of cases that appear in multimedia are taken from the eruption of Mount Merapi phenomenon which until now is still active. The photos and videos produced are great for describing the impacts and mitigation/adaptation efforts of communities on volcanic eruptions.

- Tidal floods learning Multimedia

Photos and videos that featured in tidal flood multimedia are deliberately recorded at the time the tidal flood is in progress. the pictures recordingdone on the Sayung beach, Demak Regency and on the north coastal of Semarang city. For clearly show the tidal floods processes 
a combination of animation with video was made.

The four learning multimedia mentioned has faced validation from the content experts and media experts with 'excelent' grade.

\section{B. Student Response About The Use of Disaster Learning Multimedia}

Students' responses about the use of disaster learningmultimedia were only gained from students in the experimental classes. The table below is the answer to the 10 questions in the questionnaire that given to 116 students in four schools where the disaster learning experiment was conducted.

Table 1. Student's responce (in percent)

\begin{tabular}{|c|c|c|c|c|c|}
\hline No & Student's Response & SA & A & LA & DA \\
\hline & Disaster learning multimedia can: & & & & \\
\hline 1 & $\begin{array}{c}\text { Clearlyshow the process of } \\
\text { disaster }\end{array}$ & 77 & 13 & 0 & 0 \\
\hline 2 & $\begin{array}{c}\text { Make learning process more } \\
\text { interesting }\end{array}$ & 82 & 18 & 0 & 0 \\
\hline 3 & $\begin{array}{c}\text { Cause students to give no attention } \\
\text { toward the lesson }\end{array}$ & 0 & 10 & 55 & 35 \\
\hline 4 & Make learning more fun & 75 & 20 & 5 & 0 \\
\hline 5 & Make students more focused & 62 & 25 & 13 & 0 \\
\hline 6 & Understand the impact of disasters & 30 & 70 & 0 & 0 \\
\hline 7 & Disturbing student concentration & 0 & 10 & 55 & 35 \\
\hline 8 & Allows students to be more active & 10 & 52 & 30 & 8 \\
\hline 9 & Make students more critical & 34 & 48 & 18 & 0 \\
\hline 10 & Make the material easier to \\
remember & 80 & 20 & 0 & 0 \\
\hline & Notes: SA=strongly agree; A= agree; LA = less agree; DA= \\
& disagree
\end{tabular}

The table above shows that generally students have a positive response to the utilization of disaster learning multimedia among others, because it is easier to understand the material, causing students to be more creative, fun classroom atmosphere, not boring and so on. The use of multimedia elements in creating the learning contents makes the learning experiences more meaningful. It becomes an important component in learning as it provides the students with an alternative means to have more choices when learning in the student centred learning environment. The learning attitudes changed as the students realised that learning with multimedia was more flexible in exploring and constructing new knowledge. This has engaged the students and boosted their learning interest in this studentcentred environment (Leo and Neo, 2014). Students can navigate to the source of information in a shorter time, build the connections between relevant topics, and construct their knowledge by associating to the meaningful information (Hede $\&$ Hede, 2002; Parekh, 2006). In addition to these, multimedia technology has been shown to affect students' motivation and self-esteem levels, as well as allow them to become creative and selfdirected thinkers (Agnew, Kellerman \& Meyer, 1996).

\section{Effectiveness of Disaster Learning Multimedia to Improve Student Preparedness}

- Information literacy The result of statistic test in the experiment using the flood learning multimedia showed: the experimental class test results (14 - 18), control class (11-15), $\mathrm{t}_{\text {observation }}=3,750 ; \mathrm{t}_{\text {table }}=2.028$ which means $t_{\text {obs }}>t_{\text {tableshowing the difference of disaster }}$ preparedness between control class and the experimental class. In addition, the significance value between the two models $0.00<\alpha=0.05$ which means learning using flood multimedia is more effective to raise students preparedness toward disasterrather than those who do not use multimedia.

- The result of statistic test in the experimentusing the landslides learning multimedia showed: the experimental class test results $(13-18)$, control class $(11-14), \mathrm{t}_{\mathrm{obs}}$ $=2,750 ; t_{\text {table }}=2.028$ which means $t_{\text {obs }}>$ $t_{\text {tableshowing the difference of disaster }}$ preparedness between control class and the experimental class. In addition, the significance value between the two models $0.00<\alpha=0.05$ which means learning using landslide multimedia is more effective to raise students preparedness toward disaster than those who do not use multimedia.

- The result of statistic test in the experimentusing the eruption learning multimedia showed: the experimental class test results $(14-18)$, control class $(9-15), \mathrm{t}_{\mathrm{obs}}=$ 4,$944 ; \quad t_{\text {table }}=2.028$ which means $t_{\text {obs }}>$ $t_{\text {tableshowing the difference of disaster }}$ preparedness between control class and the experimental class. In addition, the significance value between the two models $0.00<\alpha=0.05$ which means learning using eruption learning multimedia is more effective to raise students preparedness toward disaster than those who do not use multimedia.

- The result of statistic test in the experiment using the tidal flood learning multimedia showed: the experimental class test results (14 - 18), control class (11-15), $\mathrm{t}_{\mathrm{obs}}=3,750$; $\mathrm{t}_{\text {table }}=2.028$ which means $\mathrm{t}_{\mathrm{obs}}>\mathrm{t}_{\text {tables }}$ showing the difference of disaster preparedness between control class and the experimental class. In addition, the significance value between the two models $0.00<\alpha=0.05$ which means learning using tidal flood multimedia is more effective to raise students preparedness toward disaster than those who do not use multimedia. It can be concluded that there is a significant difference between a class that uses disaster 
multimedia and the one which does not use multimedia learning or in other words the use of disaster learning multimedia can effectively improve student disaster preparedness.

\section{CONCLUSION}

1. This research has sucessfully develop four disaster learning multimedia namely flood, landslide, eruption, and tidal flood. The superiority of this learning multimedia are the description which use simple term and language, most of the photos and video which are recorded in the real life phenomenon around the site, and the animation which was created by the research team.

2. Most of the students had possitive responses toward the disaster learning multimedia which mentioned that it cused the learning process become more interesting, not boring, made the students become more active and creative, and increase the clarity of the materials.

3. The use of the learning multimedia was effective in improving the students' preparedness toward disaster

\section{ACKNOWLEDGMENTS}

The research team would thank and praise DIKTI for granting this research through Hibah Penelitian Unggulan Perguruan Tinggiin 2015-2016.

\section{REFERENCES}

[1] Aziz, A. \& Rahardjo, P. (2013). Faktor-faktor Amri, A.: 2015.Challenges in implementing disaster risk reduction education:Views from the frontline in Indonesia, Macquarie University,Sydney, Australia,

[2] Amri. A. 2017. Disaster risk reduction education in Indonesia: challenges and recommendations for scaling up. Nat. Hazards Earth Syst. Sci., 17, 595-612, 2017

[3] Badan Penanggulangan Bencana Nasional. 2017. Kejadian bencana di Indonesia tahun 2017. BNPB. http://dibi.bnpb.go.id

[4] Crichton \& Kopp. (2006) . Multimedia technologies, Multiple Intelligences, and Teacher ProfessionalDevelopment International education project. Innovative Online, dari http://www.innovateonline.info/pdf/vol2_issue3/ Multimedia_Technologies, _diakses 20 Oktober 2014

[5] Demeter, K. Using Multimedia Technology to Scale up Disaster Risk Management Training http://siteresources.worldbank.org/CMUDLP/Resources/Andr ei_Katalin_web.pdf

[6] Hede, T. \& Hede, A. (2002). Multimedia effects on learning: Design implications of an integrated model. In McNamara, S. \& Stacey, E. (Ed), Untangling the Web: Establishing Learning Links. Proceedings of ASET Conference 2002 [Online]. Available: http://www.aset.org.au/confs/2002/hedet.html

[7] Leow Fui-Theng and Neo Mai. 2014. Interactive Multimedia learning Innovating Classroom Education in a Malaysian University. The Turkish Online Journal of Educational Technology - April 2014, volume 13 issue 2

[8] Parekh, R. (2006). Principles of Multimedia. New Delhi: Tata McGraw-Hill.

[9] UNICEV. 2011. Teaching Disaster Risk Reduction with Interactive Methods. Tbilisi: National Curriculum and Assessment Centre

[10] UNISDR . 2005. Hyogo Framework fo Action 2005-2015: International Strategy for Disaster Reduction. UNISDR Geneva, Switzerland,. www.unisdr.org/wcdr

[11] United Nations: Yokohama Strategy and Plan of Action for a Safer World: guidelines for natural disaster prevention, preparedness and mitigation, United Nations, Yokohama, Japan, 1994. 